\title{
Knowledge and skills in chest auscultation among nurses
}

Wiedza i umiejętności z zakresu osłuchiwania klatki piersiowej wśród pielęgniarek

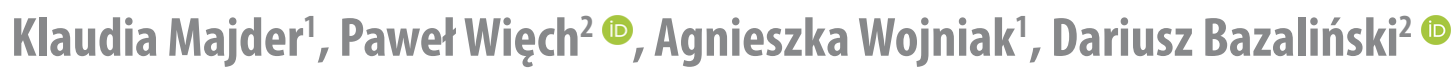

'Student Scientific Club of Emergency Medicine, College of Medical Sciences, University of Rzeszów, Rzeszów ${ }^{2}$ Institute of Health Sciences, College of Medical Sciences, University of Rzeszów, Rzeszów

CORRESPONDING AUTHOR/AUTOR DO KORESPONDENCJ:

Klaudia Majder

Uniwersytet Rzeszowski

Al. Kopisto 2a, 35-310 Rzeszów e-mail: klaudiamajder19@gmail.com

STRESZCZENIE

Słowa kluczowe:

\section{ABSTRACT}

Key words:

\section{WIEDZA I UMIEJĘTNOŚCI Z ZAKRESU OSRUCHIWANIA KLATKI PIERSIOWEJ WŚRÓD PIELĘGNIAREK}

Wprowadzenie. Wywiad oraz badanie fizykalne są podstawowymi elementami pozwalającymi pielęgniarkom ocenić stan zdrowia pacjentów. Umiejętność osłuchiwania klatki piersiowej w połączeniu z wiedzą anatomiczną i fizjologiczną daje szybką i niezawodną metodę rozróżniania i diagnozowania wielu chorób.

Cel. Celem przeprowadzonych badań była ocena wiedzy i umiejętności z zakresu osłuchiwania klatki piersiowej wśród personelu pielęgniarskiego.

Materiał i metodyka. W oparciu o założone kryteria doboru losowego do badań zakwalifikowano 51 przedstawicieli zawodu (41 kobiet i 10 mężczyzn). 0cenie poddano poziom wiedzy oraz umiejętności z zakresu osłuchiwania klatki piersiowej oraz samodzielność podejmowania tej czynności w pracy zawodowej. Wykorzystano autorski test wiedzy, kwestionariusz ankiety oraz trenażer SimScope 360-3400. Wartości p $<0.05$ uznano za statystycznie istotne.

Wyniki. 10\% badanych wykazało brak umiejętności osłuchiwania klatki piersiowej, mimo, że u żadnego z badanych nie stwierdzono braku wiedzy w tym zakresie $(p<0.001)$. Wraz z wyższym poziomem wiedzy poziom umiejętności badanych ulegał wzrostowi, a niższy poziom wiedzy warunkował niższy poziom umiejętności $(\mathrm{p}=0.049)$. W opinii badanych osłuchiwanie płuc i serca są czynnościami wykonywanymi wyłącznie przez lekarza.

Wnioski. Pomimo umiarkowanego poziomu wiedzy i umiejętności z zakresu osłuchiwania klatki piersiowej, personel pielęgniarski nie wykorzystuje technik badania fizykalnego w pracy zawodowej.

osłuchiwanie, osłuchiwanie klatki piersiowej, badanie fizykalne, pielęgniarki

\section{KNOWLEDGE AND SKILLS IN CHEST AUSCULTATION AMONG NURSES}

Introduction. Medical history and physical examination are basic elements allowing nurses to assess patients' health. The ability to auscultate the chest in combination with anatomical and physiological knowledge constitute a quick and reliable method of differentiation and diagnosis of many diseases.

Aim. The aim of the study was to assess knowledge and skills in the field of chest auscultation among nursing staff.

Material and method. A prospective, pilot observational study was conducted on a group of 51 nurses. The level of knowledge and skills in the field of chest auscultation and independence in undertaking this activity in professional work were assessed. The knowledge test developed by the author, survey questionnaire and SimScope 360-3400 trainer were used. $P<0.05$ value was considered statistically significant.

Results. Lack of chest auscultation skills was observed in $10 \%$ of the respondents, although none of them revealed lack of knowledge in this respect $(p<0.001)$. Higher level of knowledge correlated with higher level of skills of the respondents, while a lower level of knowledge conditioned a lower level of skills $(p=0.049)$. In the respondents' opinion, auscultation of the lungs and heart are activities performed only by a doctor.

Conclusions. Despite a moderate level of knowledge and skills in the field of chest auscultation, nursing staff do not use physical examination techniques in their daily work.

auscultation, chest auscultation, physical examination, nurses 


\section{INTRODUCTION}

Professional development and undertaking more and more advanced nursing and therapeutic challenges implemented mainly in conditions of outpatient care is a clear trend in national literature. Increasing professional independence is an indispensable direction of efforts to create and disseminate advanced nursing practice. Taking medical history (anamnesis) and detailed physical examination are the basic elements allowing for a comprehensive assessment of the patient's condition, diagnosis and interpretation of symptoms $[1,2]$. The ability to auscultate the chest (including the lungs and heart) in combination with anatomical and physiological knowledge gives the possibility of initial diagnosis, differentiation of ailments, determination of needs and health problems necessary to implement the nursing process $[3,4]$.

In the United States, physical examination was introduced to nursing practice in the late 1970s and early 1980s as a part of the Nurse Practitioner training. In the 1990s, in Canada and Australia, physical examination was introduced into a specialty training program $[5,6]$. In the same period, Registered Nurses in Great Britain were covered by education and training in physical examination [7]. In 1999, nurses - B. Bunt and M.A. Krisman-Scott conducted a training in Poland on health assessment and physical examination. The first legal provision authorizing Polish nurses to perform physical examination was issued in 2007 [8]. Currently, this issue is regulated by the Act of 15 July 2011 on the professions of nurse and midwife and the Regulation of the Ministry of Health of 28 February 2017 according to which, the nurse performs a physical examination as a part of diagnostic services $[9,10]$.

When reviewing the main medical databases (Polish Medical Bibliography, Polish Scientific Journals Database, Academica, National Library, CeON Library of Science), no studies were found related to chest auscultation by nurses in Poland.

\section{AIM}

The aim of the study was to assess knowledge and skills in the field of chest auscultation among nursing staff.

\section{MATERIALS AND METHOD}

Observational studies were conducted in a group of 51 nurses ( 41 women, 10 men) who were participants of the postgraduate education classes / courses. The study was conducted in March 2018, all participants gave informed consent. The study design was approved by the Bioethics Committee at the University of Rzeszów (2018/03/13d) and the study was conducted in accordance with the requirements of the Helsinki Declaration. The actual research was preceded by a pilot study on a 10-person group (February 2018). As a result of the pilot study, no serious structural defects of the research tool were found and its participants were qualified for the proper study. The following inclusion criteria were adopted: professionally active nurse, completed course on physical examination, consent to participate in the study, health condition enabling examination. Failure to meet any of these criteria resulted in exclusion from the study. The characteristics of the study group is shown in Table 1.

\section{Tab. 1. The characteristics of the study group}

\begin{tabular}{|l|c|c|}
\hline \multicolumn{1}{|c|}{ Parameter } & N & $\%$ \\
\hline Sex & 10 & $19.6 \%$ \\
\hline Men & 41 & $80.4 \%$ \\
\hline Women
\end{tabular}

\begin{tabular}{|c|c|c|}
\hline \multicolumn{3}{|l|}{ Place of residence } \\
\hline City & 24 & $47.1 \%$ \\
\hline Village & 27 & $52.9 \%$ \\
\hline \multicolumn{3}{|l|}{ Education } \\
\hline Medical high school & 13 & $25.5 \%$ \\
\hline$B S C^{*}$ & 17 & $33.3 \%$ \\
\hline$M S c^{*}$ & 21 & $41.2 \%$ \\
\hline \multicolumn{3}{|l|}{ Workplace } \\
\hline Surgery department & 49 & $96.1 \%$ \\
\hline Conservative department & 2 & $3.9 \%$ \\
\hline Age (yrs) & $34.25^{* *}$ & $7.20^{* * *}$ \\
\hline Work seniority (yrs) & $10.5^{* *}$ & $8.72^{* * * *}$ \\
\hline
\end{tabular}

$\mathrm{N}$ - number of subjects; \% - per cent; ${ }^{*}$ nursing; ${ }^{* *}$ values of arithmetic average $(\overline{\mathrm{x}}) ;{ }^{* * *}$ values of standard deviation (SD).

The level of knowledge and skills of the examined nursing staff in the field of chest auscultation and independence in undertaking this activity in professional work were assessed. The knowledge was evaluated with the test developed by the authors consisting of 10 single-choice questions. The results were classified in four categories: none (0 points), low (1-4 points), moderate (5-7 points) and high (8-10 points). From among a dozen or so murmurs / tones that are an integral part of the SimScope Trainer (hybrid simulator model 360), 1 heart tone and 2 breathing murmurs were selected for each participant. The skill level was assessed in four categories: none (0 points), low (1 point), moderate ( 2 points) and high ( 3 points). The questionnaire developed by the authors, including 10 questions, interviewed the respondents about the independence of actions taken in professional work related to the auscultation of the lungs and heart. The respondents had to assess whether: they do not have the knowledge and skills necessary to perform the abovementioned activities, have knowledge and skills but cannot do it, these activities are performed only by a doctor, they carry out these activities at the request of a doctor, they perform these activities independently - without a doctor's order.

The Statistica 13.1 package was used for statistical analysis. The Wilcoxon pair order test was used to assess intra-group variability in two populations. For the analysis of variables, only non-parametric tests were used due to the lack of compliance of the distributions of the studied variables with the normal distribution, which was verified by the Shapiro-Wilk test. The correlation of two variables not meeting the criterion of normality of distribution was determined using the Spearman rank correlation 
coefficient. The analysis of variables having the character of qualitative data was carried out using the Pearson chi-square test. $\mathrm{P}$ values $<0.05$ were considered statistically significant.

\section{RESULTS}

\section{Level of knowledge and skills in chest auscultation among nursing staff}

Comparing the level of knowledge vs. skill level among the examined nurses in the field of chest auscultation, statistically significant differences were found $(\mathrm{p}<0.001)$. Although $10 \%$ of the respondents showed a lack of chest auscultation skills, none of the respondents showed a lack of knowledge in this area. In addition, $20 \%$ of nurses rated their skill level as high, although only $10 \%$ of the respondents obtained a high level of knowledge. In the assessment of the whole group, a significant correlation was found between the level of knowledge vs. skills in chest auscultation. Along with the higher level of knowledge, the level of skills of the respondents increased. A lower level of knowledge conditioned a lower level of skill (Tab. 2).

Tab. 2. Level of knowledge and skills in the field of chest auscultation among nursing staff

\begin{tabular}{|l|c|c|c|c|}
\hline \multirow{2}{*}{ Assessment } & \multicolumn{2}{|c|}{ Level of knowledge } & \multicolumn{2}{c|}{ Level of skill } \\
\cline { 2 - 5 } & $\mathbf{n}$ & $\%$ & $\mathbf{n}$ & $\%$ \\
\hline None & 0 & $0.0 \%$ & 5 & $9.8 \%$ \\
\hline Low & 18 & $35.3 \%$ & 17 & $33.3 \%$ \\
\hline Moderate & 28 & $54.9 \%$ & 19 & $37.3 \%$ \\
\hline High & 5 & $9.8 \%$ & 10 & $19.6 \%$ \\
\hline Total & 51 & $100.0 \%$ & 51 & $100.0 \%$ \\
\hline $\begin{array}{l}\text { Level of knowledge vs. } \\
\text { level of skill }\end{array}$ & \multicolumn{3}{|c|}{$\begin{array}{l}\mathrm{Z}=5.19 \mathrm{p}<0.001 \\
\mathrm{R}=0.28 \mathrm{p}=0.049\end{array}$} \\
\hline
\end{tabular}

$\mathrm{n}$ - number of observations; \% - per cent; $Z$ - Wilcoxon pair order test result; $\mathrm{p}$ - level of significance of differences; $R$ - Spearman rank correlation value.

\section{The use of knowledge and skills in the field of chest auscultation at work by nursing staff}

In the opinion of the respondents, they do not use knowledge and skills in the field of chest auscultation at work. Auscultation of the lungs and heart are activities performed only by a doctor (Table 3 ).

Tab. 3. Independence of chest auscultation in professional work

\begin{tabular}{|l|c|c|c|c|}
\hline \multirow{2}{*}{ Options } & \multicolumn{2}{|c|}{ Lung auscultation } & \multicolumn{2}{c|}{ Heart auscultation } \\
\cline { 2 - 5 } & $\mathbf{n}$ & $\%$ & $\mathbf{n}$ & $\%$ \\
\hline Has no knowledge or skills & 6 & $11.8 \%$ & 6 & $11.8 \%$ \\
\hline $\begin{array}{l}\text { Has knowledge and skills } \\
\text { but cannot use it }\end{array}$ & 8 & $15.7 \%$ & 2 & $3.9 \%$ \\
\hline Only a physician performs it & 28 & $54.9 \%$ & 35 & $68.7 \%$ \\
\hline $\begin{array}{l}\text { This activity as ordered by } \\
\text { a doctor }\end{array}$ & 5 & $9.8 \%$ & 4 & $7.8 \%$ \\
\hline $\begin{array}{l}\text { This activity independently } \\
\text { without doctor's order }\end{array}$ & 4 & $7.8 \%$ & 4 & $7.8 \%$ \\
\hline
\end{tabular}

$n$ - number of observations; $\%$ - per cent.

\section{The impact of socio-demographic factors on the level of knowledge and skills in the field of chest auscultation among nursing staff}

No statistically significant relationship $(\mathrm{p}<0.05)$ was found between the level of knowledge and skills of the nurses surveyed and their sex, education, age and work seniority (Table 4).

Tab. 4. Impact of socio-demographic factors on the level of knowledge of chest auscultation skills

\begin{tabular}{|l|c|c|c|c|c|c|}
\hline \multirow{2}{*}{$\begin{array}{c}\text { Socio-demographic } \\
\text { factor }\end{array}$} & \multicolumn{2}{|c|}{ Level of knowledge } & \multirow{2}{*}{$\mathbf{p}$} & \multicolumn{2}{|c|}{ Level of skill } & \multirow{2}{*}{$\mathbf{p}$} \\
\cline { 2 - 3 } \cline { 5 - 6 } & $\mathbf{X}^{\mathbf{2}}$ & $\mathbf{R}$ & & $\mathbf{X}^{\mathbf{2}}$ & $\mathbf{R}$ & \\
\hline Sex & 3.87 & - & 0.144 & 0.78 & - & 0.854 \\
\hline Education & 6.09 & - & 0.193 & 2.76 & - & 0.837 \\
\hline Age & - & -0.11 & 0.462 & - & 0.13 & 0.366 \\
\hline Work seniority & - & -0.13 & 0.358 & - & 0.05 & 0.707 \\
\hline
\end{tabular}

$X^{2}$ - Pearson chi-square test result; $R$-Spearman rank correlation value; $p$ - level of significance of differences.

\section{DISCUSSION}

The conducted research concerned the assessment of knowledge and skills in the field of chest auscultation among nursing staff. Selected socio-demographic variables were analyzed and nurses' opinion on practical implications in their professional work was assessed.

In our study, the knowledge and skills of nurses in the field of chest auscultation were at a moderate level, and socio-demographic factors, such as age, sex, work seniority, type of workplace, education, did not determine these skills. According to Giddens, the academic education draws attention to too detailed theoretical preparation, rarely used in professional practice [11]. Anderson B. et al. share the above view, claiming that curricula are becoming more and more extensive, which necessitates their implementation in order to bridge the gap between theory and practice [12].

In the our study, $54.9 \%$ of the respondents, when asked about self-reliance in physical examination of the chest, stated that this activity was performed only by a doctor. Every tenth respondent performs this activity independently, without a medical order. Surveys conducted by Birks M. et al. on a group of 1220 Australian nurses found that chest auscultation is not performed (35.5\%) or rarely (31\%) [13]. In a study by Cicolini G. et al. concerning Italian nurses, $60 \%$ of the respondents indicated that auscultation of breathing murmurs and heart tones was almost never practiced by them in their professional work, despite theoretical preparation during education [14].

Research by Maben J. et al. confirmed that there is a huge gap between theory and practice in nursing, which was also confirmed in our study. It has also been shown that knowledge acquired during education is not practiced in departments. The authors argue that the education of nursing staff with an emphasis on the practical application of acquired skills in subsequent work seems to be the overarching activity [15]. This observation should be thoroughly investigated, what inhibits the promotion of advanced practice for professional care for the sick and healthy person. 
To increase the level of knowledge and skills in the field of chest auscultation among nursing staff and their use in professional work, it is necessary to implement a mentoring system run by experienced nursing clinicians who will prepare next young professionals. Classes and exams in the field of physical examination should take place in Medical Simulation Centers. Educating nursing staff in facilities equipped with technologically advanced simulators will enable nurses to gain appropriate skill, reduce mistakes and correctly apply physical examination techniques in their professional work.

\section{CONCLUSIONS}

The knowledge and skills in the field of chest auscultation among nurses are at a moderate level, and age, sex, seniority and education have no significant impact. Nursing staff do not use knowledge and skills in chest auscultation at work.

\section{Wiedza i umiejętności z zakresu osłuchiwania klatki piersiowej wśród pielęgniarek}

\section{WPROWADZENIE}

Rozwój zawodowy i podejmowanie coraz bardziej zaawansowanych zadań pielęgnacyjno-terapeutycznych realizowanych głównie (choć nie tylko) w warunkach opieki niestacjonarnej nad pacjentem jest mocno zauważalny w literaturze krajowej. Zwiększenie samodzielności zawodowej jest nieodzownym kierunkiem dążeń do stworzenia i upowszechnienia zaawansowanej praktyki pielęgniarskiej. Zebranie wywiadu (badanie podmiotowe) oraz szczegółowe badanie fizykalne (badanie przedmiotowe) są podstawowymi elementami pozwalającymi na dokonanie pełnej oceny stanu zdrowia chorego, rozpoznanie oraz zinterpretowanie występujących objawów $[1,2]$. Umiejętność osłuchiwania klatki piersiowej (w tym płuc i serca) w połączeniu $z$ wiedzą anatomiczną i fizjologiczną daje możliwość wstępnego diagnozowania, różnicowania dolegliwości chorobowych, określenia potrzeb i problemów zdrowotnych niezbędnych do realizacji procesu pielęgnowania $[3,4]$.

W Stanach Zjednoczonych badanie przedmiotowe do praktyki pielęgniarskiej wprowadzono na przełomie lat 70 . i 80. XX wieku jako element szkolenia Nurse Practitioner. W latach 90. w Kanadzie i Australii wprowadzono je do cyklu kształcenia w ramach szkolenia specjalizacyjnego $[5,6]$. W tym samym okresie edukacją oraz szkoleniem z zakresu badania fizykalnego objęto pielęgniarki dyplomowane (Registered Nurses) w Wielkiej Brytanii [7]. W 1999 r. pielęgniarki - B. Bunt i M.A. Krisman-Scott przeprowadziły w Polsce szkolenie dotyczące oceny stanu zdrowia i badania przedmiotowego. Pierwszy prawny zapis uprawniający polskie pielęgniarki do wykonywania badania fizykalnego pochodzi z 2007 r. [8]. Obecnie kwestię tą reguluje ustawa $z$ dnia 15 lipca 2011 r. o zawodach pielęgniarki i położnej oraz rozporządzenie $\mathrm{MZ}$ z dnia 28 lutego 2017 r., zgodnie z którymi pielęgniarka wykonuje badanie fizykalne w ramach świadczeń diagnostycznych $[9,10]$.

Dokonując przeglądu głównych baz medycznych (Polska Bibliografia Lekarska, Polish Scientific Journals Database, Academica, Biblioteka Narodowa, CeON
Biblioteka Nauki) nie znaleziono badań związanych z osłuchiwaniem klatki piersiowej przez pielęgniarki w Polsce.

\section{CEL PRACY}

Celem przeprowadzonych badań była ocena wiedzy i umiejętności z zakresu osłuchiwania klatki piersiowej wśród personelu pielęgniarskiego.

\section{MATERIAŁ I METODYKA}

Badania obserwacyjne zostały przeprowadzone w grupie 51 przedstawicieli zawodu (41 kobiet, 10 mężczyzn), którzy byli uczestnikami zajęć/kursów w ramach kształcenia podyplomowego. Przeprowadzono je w marcu 2018 roku, wszystkie osoby biorące udział w badaniach wyraziły na nie zgodę. Projekt badania został zatwierdzony przez Komisję Bioetyczną przy Uniwersytecie Rzeszowskim (2018/03/13d), przeprowadzono je zgodnie z wymogami Deklaracji Helsińskiej. Badania właściwe poprzedzono badaniem pilotażowym na 10-osowej grupie (luty 2018 roku). W wyniku badania pilotażowego nie stwierdzono poważnych wad strukturalnych narzędzia badawczego, osoby biorące w nim udział zakwalifikowano do badania właściwego. Przyjęto następujące kryteria włączenia: czynne wykonywanie zawodu pielęgniarki/rza, ukończony kurs w zakresie badania fizykalnego, zgoda na udział w badaniu, stan zdrowotny umożliwiający przeprowadzenie badań. Brak spełniania któregokolwiek z tych kryteriów stanowił o wykluczeniu z badania. Charakterystykę badanej grupy przedstawiono w tabeli 1

Ocenie poddano poziom wiedzy oraz umiejętności badanego personelu pielęgniarskiego z zakresu osłuchiwania klatki piersiowej oraz samodzielność podejmowania tej czynności w pracy zawodowej. Poziom wiedzy zbadano za pomocą autorskiego testu wiedzy, składającego się z 10 pytań jednokrotnego wyboru. Oceniono go w czterech kategoriach: brak (0 pkt.), niski (1-4 pkt.), umiarkowany (5-7 pkt.) oraz wysoki (8-10 pkt.). Spośród kilkunastu 
Tab. 1. Charakterystyka badanej grupy

\begin{tabular}{|l|c|c|}
\hline \multicolumn{1}{|c|}{ Parametr } & N & $\%$ \\
\hline Płeć & 10 & $19.6 \%$ \\
\hline Mężczyźni & 41 & $80.4 \%$ \\
\hline Kobiety & 24 & $47.1 \%$ \\
\hline Miejsce zamieszkania \\
\hline Miasto & 27 & $52.9 \%$ \\
\hline Wieś & 13 & $25.5 \%$ \\
\hline Wykształcenie & 17 & $33.3 \%$ \\
\hline Średnie medyczne & 21 & $41.2 \%$ \\
\hline Studia wyższe I stopnia* & \\
\hline Studia wyższe Il stopnia* & \\
\hline Miejsce pracy & 49 & $96.1 \%$ \\
\hline Oddział zabiegowy & 2 & $3.9 \%$ \\
\hline Oddział zachowawczy & $34.25^{* *}$ & $7.20^{* * * *}$ \\
\hline Wiek (w latach) & $10.5^{* *}$ & $8.72^{* * *}$ \\
\hline Staż pracy (w latach)
\end{tabular}

$\mathrm{N}$ - liczba badanych; \% - procent; * pielęgniarstwo; ${ }^{* *}$ wartości dot. średniej arytmetycznej $(\overline{\mathrm{x}}) ;{ }^{* * *}$ wartości dot. odchylenia standardowego (SD).

szmerów/tonów będących integralną częścią Trenażera SimScope (symulator hybrydowy model 360), wylosowano każdej badanej osobie 1 ton sercowy oraz 2 szmery oddechowe. Poziom umiejętności oceniono w czterech kategoriach: brak (0 pkt.), niski (1 pkt.), umiarkowany (2 pkt.) oraz wysoki (3 pkt.). W autorskim kwestionariuszu ankiety, składającym się z 14 pytań zamkniętych, zapytano respondentów o samodzielność podejmowanych działań w pracy zawodowej związaną z osłuchiwaniem płuc i serca. Badani mieli za zadanie ocenić czy: nie posiadają wiedzy oraz umiejętności do wykonania ww. czynności, posiadają wiedzę oraz umiejętności lecz nie mogę tego wykonywać, czynności te wykonuje tylko lekarz, czynności te wykonują na zlecenie lekarza, czynności te wykonuja samodzielnie, bez zlecenia lekarza.

Do analizy statystycznej wykorzystano pakiet Statistica 13.1. Test kolejności par Wilcoxona użyto do oceny zmienności wewnątrzgrupowej w dwóch populacjach. Do analizy zmiennych wykorzystano wyłącznie testy nieparametryczne $\mathrm{z}$ powodu braku zgodności rozkładów badanych zmiennych z rozkładem normalnym, który zweryfikowano testem Shapiro-Wilka. Korelację dwóch zmiennych niespełniających kryterium normalności rozkładu określono przy pomocy współczynnika korelacji rang Spearmana. Analiza zmiennych mających charakter danych jakościowych przeprowadzona została przy użyciu testu chi-kwadrat Pearsona. Wartości p $<0.05$ uznano za statystycznie istotne.

\section{WYNIKI}

\section{Poziom wiedzy i umiejętności w zakresie osłuchiwania klatki piersiowej wśród personelu pielęgniarskiego}

Zestawiając ze sobą poziom wiedzy vs. poziom umiejętności badanych pielęgniarek/rzy z zakresu osłuchiwania klatki piersiowej, wykazano istotne statystycznie różnice $(\mathrm{p}<0.001)$. Mimo, że $10 \%$ badanych wykazało brak umiejętności osłuchiwania klatki piersiowej, u żadnego $\mathrm{z}$ badanych nie stwierdzono braku wiedzy w tym zakresie. Ponadto, u 20\% pielęgniarek poziom umiejętności oceniono jako wysoki, mimo, że wysoki poziom wiedzy uzyskało tylko $10 \%$ przebadanych. W ocenie całej grupy stwierdzono istotną korelację pomiędzy poziomem wiedzy vs. umiejętności w zakresie osłuchiwania klatki piersiowej. Wraz z wyższym poziomem wiedzy poziom umiejętności badanych ulegał wzrostowi. Niższy poziom wiedzy warunkował niższy poziom umiejętności (Tab. 2)

Tab. 2. Poziom wiedzy i umiejętności z zakresu osłuchiwania klatki piersiowej wśród personelu pielęgniarskiego

\begin{tabular}{|l|c|c|c|c|}
\hline \multirow{2}{*}{\multicolumn{1}{c|}{ Ocena }} & \multicolumn{2}{|c|}{ Poziom wiedzy } & \multicolumn{2}{c|}{$\begin{array}{c}\text { Poziom } \\
\text { umiejętności }\end{array}$} \\
\cline { 2 - 5 } & $\mathbf{n}$ & $\%$ & $\mathbf{n}$ & $\%$ \\
\hline Brak wiedzy/umiejętności & 0 & $0.0 \%$ & 5 & $9.8 \%$ \\
\hline Niski & 18 & $35.3 \%$ & 17 & $33.3 \%$ \\
\hline Średni & 28 & $54.9 \%$ & 19 & $37.3 \%$ \\
\hline Wysoki & 5 & $9.8 \%$ & 10 & $19.6 \%$ \\
\hline Razem & 51 & $100.0 \%$ & 51 & $100.0 \%$ \\
\hline $\begin{array}{l}\text { Poziom wiedzy vs. } \\
\text { poziom umiejętności }\end{array}$ & \multicolumn{3}{|c|}{$\begin{array}{c}\mathrm{Z}=5.19 \mathrm{p}<0.001 \\
\mathrm{R}=0.28 \mathrm{p}=0.049\end{array}$} \\
\hline
\end{tabular}

$\mathrm{n}$ - liczba obserwacji; \% - procent; $Z$ - wynik testu kolejności par Wilcoxona; $\mathrm{p}$ - poziom istotności różnic $\mathrm{R}$ - wartość korelacji rang Spearmana.

\section{Wykorzystanie wiedzy i umiejętności z zakresu osłuchiwania klatki piersiowej w pracy przez personel pielęgniarski}

W opinii badanych nie wykorzystują oni wiedzy oraz umiejętności z zakresu osłuchiwania klatki piersiowej w pracy zawodowej. Osłuchiwanie płuc i serca są czynnościami wykonywanymi wyłącznie przez lekarza (Tab. 3).

Tab. 3. Samodzielność osłuchiwania klatki piersiowej w pracy zawodowej

\begin{tabular}{|l|c|c|c|c|}
\hline \multirow{2}{*}{ Opcje } & \multicolumn{2}{|c|}{ Osłuchiwanie płuc } & \multicolumn{2}{c|}{ Osłuchiwanie serca } \\
\cline { 2 - 5 } & $\mathbf{n}$ & $\%$ & $\mathbf{n}$ & $\%$ \\
\hline $\begin{array}{l}\text { Nie posiada wiedzy } \\
\text { oraz umiejętności }\end{array}$ & 6 & $11.8 \%$ & 6 & $11.8 \%$ \\
\hline $\begin{array}{l}\text { Posiada wiedzę oraz } \\
\text { umiejętności lecz nie może } \\
\text { tego wykonywać }\end{array}$ & 8 & $15.7 \%$ & 2 & $3.9 \%$ \\
\hline $\begin{array}{l}\text { Czynność tą wykonuje tylko } \\
\text { lekarz }\end{array}$ & 28 & $54.9 \%$ & 35 & $68.7 \%$ \\
\hline $\begin{array}{l}\text { Czynność tą wykonuje } \\
\text { na zlecenie lekarza }\end{array}$ & 5 & $9.8 \%$ & 4 & $7.8 \%$ \\
\hline $\begin{array}{l}\text { Czynność tą wykonuje } \\
\text { samodzielnie, bez zlecenia } \\
\text { lekarza }\end{array}$ & 4 & $7.8 \%$ & 4 & $7.8 \%$ \\
\hline
\end{tabular}

n-liczba obserwacji; \% - procent. 


\section{Wpływ czynników socjo-demograficznych na poziom wiedzy i umiejętnosci w zakresie osłuchiwania klatki piersiowej wśród personelu pielęgniarskiego}

Nie stwierdzono istotnej statystycznie zależności $(\mathrm{p}<0.05)$ pomiędzy poziomem wiedzy i umiejętności badanych pielęgniarek/rzy a ich płcią, wykształceniem, wiekiem i stażem pracy (Tab. 4).

Tab. 4. Wpływ czynników socjo-demograficznych na poziom wiedzy umiejętności z zakresu osłuchiwania klatki piersiowej

\begin{tabular}{|l|c|c|c|c|c|c|}
\hline \multirow{2}{*}{$\begin{array}{c}\text { Czynnik socjo- } \\
\text { demograficzny }\end{array}$} & \multicolumn{2}{|c|}{ Poziom wiedzy } & \multirow{2}{*}{$\mathbf{p}$} & \multicolumn{2}{c|}{$\begin{array}{c}\text { Poziom } \\
\text { umiejętności }\end{array}$} & \multirow{2}{*}{$\mathbf{p}$} \\
\cline { 2 - 5 } & $\mathbf{X}^{\mathbf{2}}$ & $\mathbf{R}$ & & $\mathbf{X}^{\mathbf{2}}$ & $\mathbf{R}$ & \\
\hline Płeć & 3.87 & - & 0.144 & 0.78 & - & 0.854 \\
\hline Wykształcenie & 6.09 & - & 0.193 & 2.76 & - & 0.837 \\
\hline Wiek & - & -0.11 & 0.462 & - & 0.13 & 0.366 \\
\hline Staż pracy & - & -0.13 & 0.358 & - & 0.05 & 0.707 \\
\hline
\end{tabular}

$X^{2}$ - wynik testu chi-kwadrat Pearsona; $R$ - wartość korelacji rang Spearmana; $p$ - poziom istotności różnic.

\section{DYSKUSJA}

Przeprowadzone badania dotyczyły oceny wiedzy i umiejętności z zakresu osłuchiwania klatki piersiowej wśród personelu pielęgniarskiego. Poddano analizie wybrane zmienne socjo-demograficzne oraz oceniono ich opinię na temat praktycznych implikacji w wykonywanej prace zawodowej.

W badaniach własnych wiedza i umiejętności pielęgniarek i pielęgniarzy z zakresu osłuchiwania klatki piersiowej były na poziomie umiarkowanym, a czynniki socjo-demograficzne takie jak: wiek, płeć, staż pracy, typ miejsca pracy, wykształcenie nie warunkowały tych umiejętności. Według Santos i wsp. brak pewności odnośnie własnych umiejętności, przeciążenie pracą, niewystarczające zasoby materialne oraz niewystarczająca wiedza i umiejętności znacząco wpływają na ograniczenie wykorzystania badanie fizykalne w praktyce szpitalnej przez pielęgniarki [11].

Badania przeprowadzone przez Maben J. i wsp. potwierdziły, że istnieje potężna luka między teorią a praktyką w pielęgniarstwie, co potwierdzono także w badaniach własnych. Wykazano także, że wiedza wyniesiona w toku kształcenia nie jest praktykowana na oddziałach. Autorzy twierdzą, że edukacja personelu pielęgniarskiego z naciskiem na praktyczne stosowanie nabywanych umiejętności w późniejszej pracy zawodowej wydaje się być działaniem nadrzędnym [12]. Anderson B. i wsp. podzielają powyższy pogląd twierdząc, że programy nauczania są coraz bardziej obszerne, co powoduje konieczność ich racjonalizacji, tak aby zniwelować lukę między teorią a praktyką [13]. Obserwacja ta powinna być wnikliwie zbadana co stoi na przeszkodzie w propagowaniu zaawansowanej praktyki służącej do profesjonalnej opieki nad chorym jak i zdrowym człowiekiem.

W badaniu własnym $54.9 \%$ respondentów zapytanych o samodzielność podejmowania działań w badaniu przedmiotowym klatki piersiowej stwierdziło, że czynność tą wykonuje tylko lekarz. Co dziesiąty badany czynność tą wykonuje samodzielnie, bez zlecenia lekarskiego. W badaniach ankietowych przeprowadzonych przez Birks M. i wsp. na grupie 1220 australijskich pielęgniarek stwierdzono, że osłuchiwanie klatki piersiowej nie jest wykonywane (35.5\%) lub rzadko wykonywane (31\%) [14]. W badaniu Cicolini G. i wsp. dotyczącym włoskich pielęgniarek $60 \%$ badanych wskazało, że osłuchanie szmerów oddechowych oraz tonów serca prawie nigdy nie było przez nie praktykowane w pracy zawodowej, pomimo przygotowania teoretycznego w toku kształcenia [15].

Aby zwiększyć poziom wiedzy i umiejętności w zakresie osłuchiwania klatki piersiowej wśród personelu pielęgniarskiego oraz ich wykorzystanie w pracy zawodowej należy wdrożyć system mentorski prowadzony przez doświadczonych klinicystów pielęgniarstwa, którzy będą przygotowywać kolejnych młodych przedstawicieli zawodu. Zajęcia oraz egzaminy z zakresu badania fizykalnego powinny odbywać się w Centrach Symulacji Medycznej. Kształcenie personelu pielęgniarskiego w obiektach wyposażonych w zaawansowane technologicznie symulatory umożliwi im nabranie odpowiedniej wprawy, ograniczenie popełnianych błędów oraz prawidłowe stosowanie technik badania fizykalnego w pracy zawodowej.

\section{WNIOSKI}

Wiedza i umiejętności w zakresie osłuchiwania klatki piersiowej wśród pielęgniarek/rzy są na poziomie przeciętnym, a wiek, płeć, staż pracy, wykształcenie nie mają istotnego wpływu. Personel pielęgniarski nie wykorzystuje wiedzy oraz umiejętności z zakresu osłuchiwania klatki piersiowej w pracy zawodowej.

\section{ORCID}

PawełWięch (iD https://orcid.org/0000-0002-0101-1030 Dariusz Bazaliński iD https://orcid.org/0000-0003-1717-1319

\section{REFERENCES/PIŚMIENNICTWO}

1. Padykuła M, Czaja E, Pieczyrak-Brhel U, Kózka M. Znaczenie badania fizykalnego w pielęgniarstwie neurologicznym. Pielęg XXI w. 2017;4 (61): 46-51.

2. McElhinney E. Factors which influence nurse practitioners ability to carry out physical examination skills in the clinical area after a degree level module - an electronic Delphi study. J Clin Nurs. 2010;19 (21-22): 3177-3187.

3. Sarkar M, Madabhavi I , Niranjan N, Dogra M. Auscultation of the respiratory system. Ann Thorac Med. 2015;10 (3): 158-168.

4. Elder A, Japp A, Verghese A. How valuable is physical examination of the cardiovascular system? BMJ 2016; 354:i3309.

5. Secrest JA, Norwood BR, duMont PM. Physical assessment skills: a descriptive study of what is taught and what is practiced. J Prof Nurs. 2005;21 (2): 114-118.

6. Lont KL. Physical assessment by nurses: a study of nurses' use of chest auscultation as an indicator of their assessment practices. Contemp Nurse. 1992;1 (2): 93-97.

7. Raleigh M, Allan H. A qualitative study of advanced nurse practitioners' use of physical assessment skills in the community: shifting skills across professional boundaries. J Clin Nurs. 2017;26 (13-14): 2025-2035.

8. Regulation of the Minister of Health of 07.11 .2007 regarding the type and scope of preventive, diagnostic, therapeutic and rehabilitation services provided by a nurse or midwife independently without a medical order. Journal of Laws of 2007 №. 210 item 1540..

9. Act of 15.07.2011 on the Profession of a Nurse and Midwife. Journal of Laws 2011 №. 174 item 1039. 
Klaudia Majder, Paweł Więch, Agnieszka Wojniak, Dariusz Bazaliński

10. The Regulation of the Minister of Health of February 28,2017 regarding the type and scope of preventive, diagnostic, therapeutic and rehabilitation services provided by a nurse or midwife independently without a medical order. Journal of Laws of 2017 item 497.

11. Santos LA, Ferreira $L$, et al. Physical examination in nurses' hospital practice. Research, Society and Development, Itabira, v. 9, n. 7, p. e132973794, may 2020. ISSN 2525-3409.

12. Maben J, Latter S, Clark JM. The theory-practice gap: impact of professionalbureaucratic work conflict on newly-qualified nurses. J Adv Nurs. 2006;55 (4): 46577.

13. Anderson B, Nix E, Norman B, McPike HD. An evidence based approach to undergraduate physical assessment practicum course development. Nurse Educ Pract. 2014;14 (3): 242-246.

14. Birks $M$, Cant $R$, James $A$ et al. The use of physical assessment skills by registered nurses in Australia: issues for nursing education. Collegian. 2013;20 (1): 27-33.

15. Cicolini $G$, Tomietto $M$, Simonetti V et al. Physical assessment techniques performed by Italian registered nurses: a quantitative survey. J Clin Nurs. 2015; 24 (23-24): 3700-6.
Manuscript received/Praca zgłoszona do czasopisma: 26.05.2020

Manuscript accepted/Praca zaakceptowana do druku: 10.07.2020

Translation/Tłumaczenie: Anna Nowak Tłumaczenia, Nauka Języka Angielskiego 